\title{
MANAGEMENT BY VALUES IN THE WORK OF INTERNATIONAL MANAGERS
}

\author{
Łukasz BURKIEWICZ ${ }^{1}$, Agnieszka KNAP-STEFANIUK ${ }^{2}$ \\ ${ }^{1}$ The Institute of Cultural Studies, The Faculty of Philosophy, Jesuit University Ignatianum in Krakow; \\ lukasz.burkiewicz@ignatianum.edu.pl, ORCID: 0000-0001-9115-0837 \\ ${ }^{2}$ The Institute of Political and Administrative Sciences, The Faculty of Education, Jesuit University Ignatianum \\ in Krakow; agnieszka.knap.stefaniuk@ignatianum.edu.pl, ORCID: 0000-0002-9201-9889 \\ * Correspondence author
}

Purpose: Values entered the area of management relatively recently, which explains why this issue has not been widely discussed in academic articles yet. As values are an important element in supporting the achievement of the company's vision, mission and goals - especially in a multicultural environment - the aim of the authors set for themselves was to define the role that management by values plays in the work of international managers.

Design/methodology/approach: The research method adopted in the article is the analysis and synthesis of subject literature and the use of secondary research. It is a mixed method, located between empirical and theoretical methods. The article first explains the essence and meaning of values in modern management and next it describes the competences of international managers and the role values play in cross-cultural management. The final sections present management by values as a way of building employee involvement and analyse the benefits of this type of management.

Findings: The authors of the article came to the conclusion that the position of managers working in a multicultural environment does not depend only on their specialist knowledge, professional qualifications, or linguistic competence. All these skills lose their importance when they are accompanied by a lack of competences necessary to successfully function in a multicultural working environment. The article discusses the key features and skills managers of multicultural teams should possess, including the ability to implement management by values.

Social implications: This article indicates the key features and skills that a manager of an intercultural team should possess. Therefore, the conclusions of the study can be used in economic practice.

Originality/value: The authors recommend that modern managers create a system of values that will contribute to the success of their business.

Keywords: values, management by values, international managers, cross-cultural management, multiculturalism.

Category of the paper: General review. 


\section{Introduction}

For the last several decades broadly understood business has witnessed a crisis of values, caused primarily by the focus on profit. In this context many people view business as a tough area of life based on the relationship between assets and liabilities, with no room for values. It is a complicated situation, because business - being based on numbers - is measurable, while values are not. However, business is changing because the environment in which it operates is changing. Just as at the beginning of the 1980s a new wave in management caused a revolution in the approach to traditional paradigms [and also drew attention to values - authors' note], similarly now we are observing a shift from focusing solely on profits to building the organizational culture based on values. Moreover, the importance of values in management should be assessed through the prism of employees' motivation and involvement. At present we can talk about the era dominated by so-called Motivation 3.0, in which internal elements, including values, play the role of motivators (Pink, 2012).

The authors of the article would like to emphasize that shared values have a positive impact on the attitudes and behaviours of employees, which translates into building a reputation, market position and brand of the company. Shared values are conductive to the development of good practices in management, effective cooperation within teams, and building good relations outside the company.

\section{The essence of and the role played by values in contemporary management}

Values in management are a relatively recent phenomenon. The first work describing their importance in this area of business was Thomas J. Peters and Robert H. Waterman's book In Search of Excellence published in 1982 (Peters, and Waterman, 2011). On the basis of their observations of the American economy, its authors suggest that entrepreneurs create a value system that will influence the success of their business. However, the term management by values 'came into use' in the second half of the 1990s after Ken Blanchard and Michael O'Connor published the results of their studies in the book Managing by values (Blanchard, and O'Connor, 1998). In a sense, they led to a revolution, as they suggested moving away from standard managerial thinking, based mainly on hard elements in management [such as systems, processes, structures] and shifting towards building such an organisational culture in which values were to become the foundation for employee involvement, the direction of the development of an organisation and the reference point in decision-making processes (Górniak, 2015). 
Following Blanchard and O'Connor's philosophy, it should be emphasized that taking action on the basis of values stems from a natural human need for agency, which is tied with personal needs and aspirations. It results from the fact that if a person feels that they are treated as an agent, they have a sense of responsibility for what they do. This feeling leads to an autonomous involvement based on internal motivation, which is a very important factor in effective performance (Górniak, 2015).

Defining the very essence of management by values, the pillars on which it is based should be mentioned: mission, values, vision, strategy and organizational culture. The first two elements - mission and values - are the stable foundations of the organization, on the basis of which the remaining, changeable elements, such as vision, strategy and organizational culture, are built (Lachowski, 2012).

\section{International managers' competences}

Cross-cultural cooperation is based on the assumption that cultures can interpenetrate and complement one another, although it should be remembered that management in a culturally diverse working environment is inextricably linked with both opportunities and threats (Nadziakiewicz, 2018). Therefore, a heavy burden of responsibility lies with the managers, who should possess adequate competences to address the threats in an adequate way. The authors of this article have discussed these issues in their previous articles (e.g. Burkiewicz, and Knap-Stefaniuk, 2019).

First of all, managers working in cross-cultural organizations should possess welldeveloped interpersonal skills, because they will allow them to avoid erroneous perception, interpretation and assessment of other people's behaviour (Winkler, 2008). Another important feature is their openness to creativity, as multicultural organisations are inherently more creative than monocultural ones. The managers' role is not limited to not stifling their co-workers' creativity, but they should do their best to encourage and stimulate them towards creative thinking (Ochieng, and Price, 2009).

International managers must also have the ability to skilfully deal with conflicts, which is facilitated by familiarity with the cultural background of their co-workers (Moczydłowska, and Kuc, 2009). The differences between employees of international organizations result not only from the national dimension, but also from its contexts, such as food, clothing, climate habits and hygiene standards (Bukowska, 2012).

It is important to emphasise here that skilful management of multicultural teams can be conducive to gaining the competitive advantage of a company by maximising the benefits and minimising the disadvantages of cultural diversity in terms of team cohesion, interpersonal conflicts and coherent activity within the main organisational goals (Cox, and Blake, 1991). 
Of course, culturally diverse teams are not free from threats, as diversity does not work well in uncertainty and complexity conditions, which can lead to misunderstandings and frustration (Winkler, 2008).

If international managers lack the above mentioned features, their teams might be ruled by stereotypes, which are a threat to the proper functioning of an organisation, and might also lead to disorders in interpersonal contacts and teamwork (Hofstede, 2001).

Managers play a special role in cross-cultural management. They should make sure that their employees understand and accept the mechanisms of the organisational culture of their company, especially if it operates on the international market. Shared values created and observed by the organisational community (managers and employees) significantly influence all activities undertaken by a company and interpersonal relations between its employees (Lipińska, 2004, p. 392).

\section{The role of values in international management}

The global financial crisis (2007-2009) made sales leaders around the world face a huge problem of the recession in the market. It turned out that the previous belief in the need to build long-term relations with customers was even more important and timely than before and must be based on making customer realize the importance of mutual relations (Dixon, and Adamson, 2011). What mattered most in the past and now are long-term relations with customers, and not only transactions and short-term relations. Such an approach must take into consideration implementing management by values.

Nowadays, the increasing complexity and volatility of the market affects the functioning of organizations, especially those operating on the international market. Employees and managers can no longer work only on the basis of rules, decisions and procedures imposed by their superiors. In building relations with their customers they must be guided by a shared mission, vision and generally accepted values.

Management by values is a very important issue in modern management, which is confirmed by the results of international studies. The Corporate Values Index $2009^{1}$ Report reveals that $77.5 \%$ of the surveyed companies (3726 in total) define their own value system (Świątek-Barylska, 2010, p. 577).

\footnotetext{
${ }^{1}$ The Corporate Values Index 2009 Report. The Corporate Values Index 2009 covered over 3800 companies from 11 countries including Poland, USA, Germany, France, Italy, the Netherlands, Spain and others. The On Board PR consulting company was responsible for the Polish part of the study (Świątek-Barylska, 2010, p. 577).
} 
It is also worth noting that the Corporate Values Index 2013 Report listed the following 10 values which are the most important in Polish companies (juxtaposed with the results obtained in other countries): quality, innovation, customer satisfaction, know-how, success, social responsibility, trust, professionalism, environment, and honesty.

Moreover, "the global results of the Corporate Values Index $2013^{2}$ demonstrated that quality, innovation, customer satisfaction and honesty are the corporate values most frequently mentioned by companies. It is worth noting that the group of three leading global values has remained unchanged since the first edition of the survey in 2006" (Rek, 2013).

It should be emphasised that the key values are the foundation for building partnership with stakeholders, and they integrate and facilitate cooperation of culturally diverse employees, inspire them to engage in their work, give them a sense of belonging and create a sense of stability in the process of change. They also have a significant impact on the development of competences that are consistent with the professed system of values and support strategic decision making, implementation of long-term goals of the company and building its competitiveness on the market (Świątek-Barylska, 2010).

The role of values, especially in a multicultural working environment, "lies not only in the fact that they provide members of the organization with information about the 'world' of the organization, but they also express explicitly and implicitly what is desirable in the behaviour of individuals and groups. They provide a basis for comparing oneself with others and offer an opportunity to influence the behaviour and attitudes of others (Lipińska, 2010, p. 127).

Today, values are the key element of the functioning of successful international companies, which are dynamic, flexible, and able to quickly adapt to changes.

It is very important to observe and promote the norms and principles which clearly indicate what is respected and appreciated in a given company, what all employees strive for, and what is the most important in building positive, long-term relations with customers. Such norms and principles allow managers of international companies, where cultural differences are a normal element of everyday life in culturally diverse teams, to make the right decisions and avoid difficult situations or misunderstandings (Świątek-Barylska, 2010).

\footnotetext{
${ }^{2}$ The Corporate Values Index 2013 covered 4300 largest companies from 13 countries and 14 industries, including over 360 companies from Poland. The idea behind developing such an index was to, among others, present differences between value systems defined by companies of different sizes operating in different countries and in different industries (/www.hbrp.pl/b/co-sie-liczy-dla-firm/QQPfvHt; accessed:17.06.2019).
} 


\section{Management by values as a method of building employee involvement in international companies}

It is worth remembering that if the management of an organization, particularly an international one, is able to create such psychological conditions which enable all its employees to accept common values, their involvement will benefit the organization and will have a positive impact on meeting its goals (Górniak, 2015).

Management by values brings expected results only when the values defined in the company are actually observed. To achieve this, employees must know, accept and identify with these values, and the managing methods and concepts implemented in a company should support the declared values. A particularly important factor in successful management by values is, above all, the respect for company values, which is demonstrated and promoted in the daily attitudes and behaviours of the management (Świątek-Barylska, 2010).

Integrating employees around shared values means declaring them and convincing people to apply them in the organisational practice. Only then will these values have an impact on building employee involvement, especially in multicultural teams.

"Employees may be guided by a declared set of values (i.e. be value-driven), but the most valuable of them are those that become values in use. Values in use have the greatest impact on the relations the organization wants to build and maintain with its stakeholders, indirectly shape the image of the company and contribute to the competitiveness of the organization (KrajewskaNieckarz, 2013, p. 217).

Values professed in the company increase the involvement of employees in cooperation while performing their tasks and affect the working atmosphere and positive perception of the company by various stakeholders (Wiśniewska, 2015, p. 203).

Moreover, "organizational values, which are expressed in concrete activities and enterprises, make the organization a reliable and valued partner for its local environment. Stephen Covey, describing a manager of a new era, builds his image by clearly emphasizing the role of values that would constitute the foundation of his work. He emphasizes that managers' tasks should include: creating a thrilling vision and mission, which instils the organizational culture and stimulates it with a great, transcendental sense of purpose, links the system of values and the vision to the needs of customers and other interest groups" (Krajewska-Nieckarz, 2013, pp. 225-226).

According to the authors of the article, the priority in management of multicultural teams should be given to search for such context of work that would inspire all members of a company (employees and managers from different cultures) to engage in its development in accordance with its mission and strategy by observing shared organizational values. 


\section{Benefits of management by values in a multicultural working environment}

The development of interest in values, management by values or value based management present in economic sciences for several decades has not decreased. The claim that it is more of an intellectual fashion in management than a permanent trend is untrue (Herman, Konopka, 2013 , p. 33). The interest in values and management by values is still valid and particularly important, especially from the perspective of management in international companies.

Undoubtedly, management by values allows organizations to meet the most important challenges of contemporary economy, and, above all, to function effectively in a cross-cultural environment (Blanchard, 2007; Drucker, 2000).

Managers working in multicultural organizations can benefit from management by values in many areas (Lachowski, 2012).

First of all, management by values helps to build the uniqueness of a company and its competitive advantage. Creating a set of values characteristic for a given organization allows it to stand out from many others on the market. In this way companies attract customers and build their loyalty, and it also refers to employees who look for exceptional employers. The creation of a value system based on mutual respect, tolerance and openness is particularly important in a multicultural working environment.

Secondly, management by values allows for effective knowledge management. If the organization focuses on independence of its employees and creates conditions for their development, creativity and innovation, it will achieve success by increasing the effectiveness of its operations. A multicultural working environment knows more, and creating the conditions in which employees will share their knowledge can be used for increasing the effectiveness of a company. It is said that "creativity thrives on diversity" (Morgan, 1989, p. 77).

Thirdly, management by values is the management method which is most likely to create an organisation that will remain on the market for a long time. Stable values are an element of the organizational culture which can serve as an inspiration for subsequent managers of a given company.

Fourthly, management by values means that employees who identify themselves with the values of their company work in the most effective way. This employee-organisational relationship can be compared to the so-called 'quality circles' introduced by the Japanese in Total Quality Management, in which employees devote their free time to their employers (Lachowski, 2012).

One of the most significant benefits of introducing such an approach is building strong relations with stakeholder groups [both internal and external - authors' note], which directly translates into effectiveness and the image of a company, strengthens its reputation, creates a strong, recognizable brand that stands out on the market, and increases the level of 
involvement and motivation of employees (Burkiewicz, 2016). It should also be remembered that values are universal and often exceed the divisions created by cultural differences.

\section{Conclusions}

Globalisation and the development of international cooperation have led to the creation of teams whose members represent different nationalities and cultures. It should always be taken into account that cooperation within multinational teams is a complex phenomenon and that the work results obtained by such teams depend on many factors. Therefore, the role of contemporary managers working in a multicultural organization can be analysed from at least several angles. First of all, it should be emphasized that the quality of their work does not depend only on the specialist knowledge, professional qualifications or linguistic competence. All these skills lose their importance when they are accompanied by the lack of competences necessary to successfully function in a multicultural working environment. It should be remembered that cultural diversity becomes a source of competitive advantage only when we have adequate skills to manage these differences (Jankowska-Mihułowicz, 2011).

The article discussed the key features and skills managers of multicultural teams should possess, including the ability to implement management by values. Following this path, the authors wish to emphasize that managers should build their authority and manage the organization on the bases of these values which are expected by their co-workers, including tolerance that is vitally important in multicultural relations. Making managers realize the role values occupy in their management style is the basis for shaping open and tolerant attitudes that promote understanding of different cultures, and leads to reducing negative effects of prejudice and the lack of appreciation of cultural diversity (Knap-Stefaniuk, 2017).

Implementing values as a central point of management in a company is a challenge for all managers working in international organizations. One of the reasons for it being so difficult is the fact that values, as the focal point of planning, deciding, organizing and controlling an organization, which were once too soft to be included in a serious approach to management, have now changed into a central part in discussions about the organizational strategy and changes.

Therefore, building a hierarchy of organisational values acceptable to all employees that will motivate the whole team, especially a multicultural team, is now very important for creating good working atmosphere, achieving the company goals effectively, and building its competitive advantage on the dynamic and changing market. 


\section{References}

1. Blanchard, K. (2007). Przywództwo wyższego stopnia. Warszawa: PWN.

2. Blanchard, K., and O’Connor, M. (1998). Zarzadzanie przez wartości. Warszawa: Studio EMKA.

3. Bukowska, U. (2012). W kierunku organizacji wielokulturowej. Zarzadzanie i Finanse, $10(1,3), 327-338$.

4. Burkiewicz, Ł. (2016). Kilka uwag do dyskusji nad etyką marketingu. In: Ł. Burkiewicz, and J. Kucharski (Eds.), Etyka w organizacji. Zarzadzanie, kultura, polityka (pp. 177-200). Kraków: Wydawnictwo Akademii Ignatianum.

5. Burkiewicz, Ł., and Knap-Stefaniuk, A. (2019). Współcześni menedżerowie w zarządzaniu międzykulturowym. Przedsiębiorczość i Zarządzanie, 20(6), 63-75.

6. Cox, T.H., and Blake, S. (1991). Managing Cultural Diversity: Implications for Organizational Competitiveness. The Executive, 5(3), 45-56.

7. Dixon, M., and Adamson, B. (2011). Sprzedawaj jak Challanger. Strategie kontroli komunikacji z klientem. Gliwice: Wydawnictwo Helion.

8. Drucker, P. (2000). Zarzadzanie w XXI wieku. Warszawa: Muza SA.

9. Górniak, L. (2015). Zarządzanie przez wartości jako metoda angażowania pracowników. Zeszyty Naukowe Uniwersytetu Ekonomicznego w Krakowie, 8(944), 101-116. doi: 10.15678/ZNUEK.2015.0944.0809.

10. Herman, A., and Konopka, D. (2013). Zarządzanie przez wartości drogą do zrównoważonego i społecznie odpowiedzialnego rozwoju. Zeszyty Naukowe Uniwersytetu Szczeińskiego, 786, Finanse, Rynki Finansowe, Ubezpieczenia, 64(1), 33-40.

11. Hofstede, G. (2001). Culture Consequences. Comparing Values, Behaviors, Institutions and Organizations Across Nations. Thousand Oaks-London-New Delhi: Sage Publications.

12. Jankowska-Mihułowicz, M. (2011). Kształtowanie organizacji wielokulturowej - strategie behawioralne. Problemy Zarzadzania, 9(4), 61-74.

13. Knap-Stefaniuk, A. (2017). Zarządzanie zasobami ludzkimi w aspekcie międzynarodowym - wybrane zagadnienia. Nowoczesne Systemy Zarzadzania, 12(2), 95-105.

14. Krajewska-Nieckarz, M. (2013). Rola wartości w zarządzaniu organizacją. Zarządzanie i Finanse, 11(1, 3), 231-238.

15. Lachowski, S. (2012). Droga ważniejsza niż cel. Wartości w życiu i biznesie. Warszawa: Studio EMKA.

16. Lipińska, J. (2010). Zarządzanie przez wartości. In: R. Knosala (Ed.), Komputerowo zintegrowane zarzadzanie (pp. 122-131), Opole: Wydawnictwo Polskiego Towarzystwa Zarządzania Produkcją.

17. Moczydłowska, J.M., and Kuc, B.R. (2009). Zachowania organizacyjne. Warszawa: Difin. 18. Morgan, G. (1989). Endangered Species: New Ideas. Business Month, 133(4), 75-77. 
19. Nadziakiewicz, M. (2018). Zarządzanie zespołem wielokulturowym w dobie migracji. Zeszyty Naukowe Politechniki Śląsiej, 126, 143-150.

20. Ochieng, E.G., and Price, A.D. (2009). Framework for managing multicultural project teams. Engineering, Construction and Architectural Management, 16(6), 527-543.

21. Peters, T.J., and Waterman, R.H. (2011). W poszukiwaniu doskonałości w biznesie. Warszawa: MT Biznes.

22. Pink, H.D. (2012). Drive. Kompletnie nowe spojrzenie na motywacje. Warszawa: Studio EMKA.

23. Rek, K. (2013). Co liczy się dla firm? Harvard Business Review Polska, https://www.hbrp.pl/b/co-sie-liczy-dla-firm/QQPfvHt1, 17.06.2019.

24. Świątek-Barylska, I. (2010). Zarządzanie przez wartości jako podstawa trwania i rozwoju organizacji: teoria i praktyka, Ekonomiczne Problemy Ustug, 58, 571-578.

25. Winkler, R. (2008). Zarządzanie komunikacją w organizacjach zróżnicowanych kulturowo. Kraków: Wolters Kluwer Polska.

26. Wiśniewska, A.M. (2015). Etyczny wymiar zarządzania w przedsiębiorstwie, Zeszyty Naukowe Uczelni Vistula, 44(6), 191-205. 